\title{
An Exploration into Gender-related Differences in Pronunciation among Libyan Learners of English as a Foreign Language
}

\author{
Hawa Mohammed Es-skare ${ }^{1}$ \\ Misurata University
}

\author{
Mariem Salem Aburawi \\ Misurata University
}

\author{
Khalifa Mohamed Shenina \\ Misurata University \\ https://doi.org/10.36602/faj.2018.n12.08
}

\begin{abstract}
This research paper mainly discussed the gender-related differences from the aspects of pronunciation, mainly intonation and stress, among Libyan students who learn English as a foreign language. The researchers have randomly selected twenty undergraduate students from the third and fourth semesters (ten female students and ten male students) from the English department, Faculty of Arts, Misurata University to participate in the research and asked to read aloud several written sentences. Their actual pronunciation was recorded and analyzed using a quantitative approach to find out if there were significant differences among female and male participants' pronunciation. The research results revealed that there were not considerable differences between female and male participants' pronunciation. Both groups have had some difficulties in recognition of the correct intonation pattern and putting the stress on the right words. Moreover, female students generally outperformed male ones, though; male participants were slightly better than female ones in identifying the accurate stressed words. Finally, it was suggested that individual differences among learners, including gender-related differences, play an important role in enhancing language teaching and learning process.
\end{abstract}

Key words: gender, pronunciation, differences, intonation, stress.

hmsaleh@art.misuratau.edu.ly 


$$
\begin{aligned}
& \text { ملخص البحث } \\
& \text { تناولت هده الورقة البحثية الاختلاف في النطق وبشكل رئيسي الترنيم (intonation) والنبرة (stress) بين الجنسين } \\
& \text { (الذكور والإناث) بين الطلبة الليبين الذين يدرسون اللغة الانجليزية كلغة أجنبية. تم اختيار عدد (20) طالبا بشكل } \\
& \text { عشوائي من الفصلين الدراسيين الثالث والرابع من قسم اللغة الانجليزية بكلية الآداب بجامعة مصراته للمشاركة في الجانب } \\
& \text { العملي من البحث. وقد طلب منهم قراءة عدد من الجمل المكتوبة بصوت عالٍ وتم تسجيل وتحليل النطق الفعلي للطلبة } \\
& \text { لمعرفة ما إذا كانت هناك اختلافات كبيرة في نطق المشاركين من الإناث والذكور. أظهرت نتائج البحث عدم وجود } \\
& \text { اختلافات كبيرة بين الجنسين. كما تبين أن كلتا المجموعتين واجهت بعض الصعوبات في التعرف على نمط الترنيم الصحيح } \\
& \text { ووضع النبرة على الكلمات المناسبة في الجمل. علاوة على ذلك، تفوقت الاناث بشكل عام على الذكور، على الرغم من } \\
& \text { أن المشاركين الذكور كانوا أفضل نوعا ما في تحديد النبرة على الكلمة الصحيحة في الجمل المعطاة. وأخيراً، يقترح الباحث } \\
& \text { أن الفروق الفردية بين المتعلمين، بما في ذلك الاختلافات المرتبطة بالنوع الاجتماعي والفروق الجنسية، تلعب دوراً هاماً في } \\
& \text { تعزيز عملية تعليم وتعلم اللغات. }
\end{aligned}
$$

\section{Introduction}

\subsection{Background and Research Problem}

The field of learning/teaching languages and gender is one of the most dynamic fields in sociolinguistics. Recently, many researches have investigated the notion of whether male and female speakers tend to speak differently (Holmes, 2013). Lakoff (1975) carried out several studies on this concept and pointed out that women are likely to use different forms of men in their conversation. The findings are ascertained by comparing a conversation between a female and male (as cited in Jinyu, 2014). According to her research findings, the difference between women and men's use of language can be determined by many factors. Their use of language might happen in distinguished conditions and contain several aspects, particularly, their pronunciation and choice of vocabulary. Many researchers have been interested in finding these differences and studying them in depth. Examining and identifying such differences among foreign language speakers can be worthy researchable.

Sociolinguistics is the study of the relationship between language use and society, and how the structures of language differ in the contexts (Wardhaugh, 2006). One of the aspects of sociolinguistics is gender differences; gender differences explain how men and women speak differently from each other (Holmes, 2013).

In the second half of the twentieth century, social science researchers and linguists gave their attention to study the differences between females and males in-depth (Holme, 2013 \& Meyerhoff, 2006). Women and men do not speak exactly the same way as each other. Male and female speakers have certain elements that characterize their speech from each other; such differences appear in utterance, choosing vocabulary, pronunciation, and intonation 
(Jinyu, 2014). Men and women pronounce the language differently. As it has been affirmed by Jinyu (2014) that "lots of linguists found women's pronunciation are more close to British pronunciation standards"(p.94).

Many researchers and sociolinguists investigated into the idea of gender differences and studied these differences from various points of view (Elwash \& Hashem, 2015; Linde, Alex, Van Verde, Hovenge \& Visage, 2013; Xia, 2013; and Xiying, 2010). They ascertained that there are many differences between females and males in different aspects; in speaking, using conflict handing, and choosing words. In addition, they have different levels of understanding the teaching strategies and instructions in foreign/second language classes.

As many other teaching environments, it has been noticed that there are gender differences in pronouncing English among EFL learners in Libya where students learn English as a foreign language. Highlighting such variations and differences might help to think of other alternatives to cope with many challenges teachers and students face in the teaching and learning process.

\subsection{Related Studies}

Sociolinguistics is defined by Oxford dictionary as the science of study the way languages are affected by differences in social class, region, and gender (2006). Nordquist (2016) also defined sociolinguistics as a category of both linguistics and sociology, and it studies the relation between language and society. Sociolinguistics studies the relationship between language and society, why language speakers speak differently in different social contexts, how to identify the social functions of languages, and the way speakers use them to convey social various meanings (Spolsky, 1998). Generally, languages vary in relation to different factors such as, dialect, class, style, and gender

Carne, Yeager, and Whitman (1981) defined dialect as the geographical variety of a language. People from different regions may vary in their dialects in terms of grammar, vocabulary, and pronunciation. Moreover, Spolsky (1998) pointed out that the dialect is a distinguishing feature of the geographical area where it is spoken.

Social class is used to define groups of speakers who have similar certain features in their speech, such as, middle class and working class. In 2006, Meyerhoff identified the social class, as it is an influence on people speech. For example, New Yorkers speak English with some classic differences which are related to the socioeconomic classes and measuring the society members according to their wealth, income, education, and occupation.

Spolsky (1998) explained that religion is another social factor, which affects languages used by their speakers. For example, in Baghdad there are three spoken dialects one spoken by Muslim, another by Christian, and a third one by Jewish people.

Style is the study of stylistic variations in a language (Lyons 1981). It is defined as a degree of formality when people speak or write, and how much they are comfortable or carful in their speech. In addition, different varieties of language might appear when people talk to friends, children, parents, teachers, or strangers (Spolsky, 1998). 
The study of gender differences is a subfield of sociolinguistics. According to Lakoff (1975), when a woman and man talk about the same topic, surprisingly, their speech will sound utterly unrelated. Holmes (1998) has identified five sociolinguistic universal tendencies between men and women's language (as cited in Wardhaugh, 2006):

- Women and men develop different patterns of language use.

- Women tend to focus on the affective functions of interaction more often than men do.

- Women tend to use linguistic devices which stress solidarity more often than men do.

- Women tend to interact in a way to maintain and increase solidarity, while men tend to interact in a way to preserve and increase their power and status.

- Women are expected to be stylistically more flexible than men are.

The notion of gender differences has been conducted by several previous studies with different results and conclusions.

Xiying (2010) studied gender differences in English learning strategies utilized by middle school students. The researcher has adopted the Oxford learning strategy questionnaire and investigated several strategies: memory, cognitive, compensation, Meta-cognitive, emotion and social communication. According to his research findings, "the development of male and female students learning strategy is imbalanced' (Xiying, 2010:p. 2). The females tend to use learning strategy more frequently, except in social communication strategy. Therefore, the females slightly win over the males.

In another aspect regards gender differences, Lakoff's research findings (1975) concluded that men and women use different types of grammar and their gender affect their choice. Women's language differ in grammar in many aspects, for example, the choice and frequency of lexical items. Men rarely use words like beige, ecru, and lavender, while women are very fond of using them. In addition, women tend to overuse qualifiers such as, I think and I guess, and there is a difference between men and women in the use of the particles such as, so and just. Furthermore, women are using tag questions more than men are.

In a study carried out by Elwash and Hashem (2015), the researchers investigated into the impact of gender and personality on second language speaking. The study has tried to find out the influence of gender on speaking a second language. Their findings have indicated that women and men use language in different ways, women's speech are found to contain more euphemisms, politeness, and female participants tend to talk more about home, family, and emotion. Contrastingly, men tend to use slangs and nonstandard forms of language and are more directive and assertive than women.

Regards pronunciation differences between female and men's language, Jinyu (2014) identified that women's pronunciation is closer to British pronunciation standards. He also added that females tend to pay more attention to their pronunciation accuracy and are always trying to make their pronunciation better. Therefore, women's pronunciation is more accurate and concise.

In Lakoff's study (1975), it has been found that women usually answer questions with raising intonation patterns rather than falling intonation. Women think that in this way they 
can show their gentleness, yet it sometimes shows a lack of confidence. On the other hand, men tend to use falling intonation patterns to show certainty, confidence, or even power. Similarly, Jinyu (2014) has affirmed that women prefer using several intonations in one sentence, while men prefer falling tones. Additionally, women usually use emphatic stress patterns in their speech to express uncertainty and use tones to emphasize certain words such as great, so, or really. For example, in the sentence: Did you know my score? Really? The word really is an example of an emphatic stress. The word can be used to strengthen the meaning of the utterances (Jinyu, 2014).

Xia (2013) investigated into gender differences in using second language. The study focused on several aspects such as, pronunciation, syntax, manner, attitude, vocabulary, and non-verbal differences. She found that most men mispronounced -ing and women prefer using reverse intonation. For example:

Husband: When will dinner be ready?

Wife: Around six o'clock.

Although, the wife is the only one knows the answer and instead of using falling intonation she uses rising intonation as a sign for asking the husband whether it is suitable for him. Xia (2013) has concluded that women's preferences include using rising tones for psychological reasons such as: timidity and emotional instability. On the contrary, men's preferences tend to use falling intonation to show they are quite sure of what they are saying or express their confidence.

\subsection{Research Questions}

The main aim of this research is to examine gender-related differences in pronunciation of Libyan speakers of English as a foreign language. It was designed to address the following specific questions:

1. Does gender influence learners' pronunciation significantly?

2. In what fields of pronunciation (intonation or stress) do male/female students perform better?

\subsection{Research Significance}

The findings of this research may be important to the administrators who can modify the courses to suit gender differences and to be proper for men and women's abilities and preferences. Additionally, teachers may find it helpful to know how to evaluate their students according to gender variations and to assist them to improve their English in general and pronunciation in particular. Furthermore, the study may help them to choose a suitable curriculum to improve students' language levels according to their individual differences. Besides, Learners of English as a foreign language can be aware of the strengths and weaknesses in English acquisition and learning, so they can work on themselves to overcome difficulties and weak points they might have.

\section{Methodology}

\subsection{Research Design}


The quantitative method was used in this study to identify gender differences among foreign language speakers. Quantitative research deals with numbers and logic, it emphasizes objective measurements and the statistical, mathematical, or numerical analysis of data collected. The overall aim of a quantitative research is to classify features, count them, and construct statistical models in an attempt to explain what was observed (Trefry, 2017). In this study, quantitative data collection methods were used by program developed test.

\subsection{Research Setting and Subjects}

The researchers have randomly selected twenty undergraduate students from the third and fourth semesters (ten female students and ten male students) during fall semester 2017 2018. The study was conducted at the Department of English, Faculty of Arts, Misurata University, Libya.

\subsection{Research Instruments}

In order to study the gender difference in female and males' pronunciation, the research subjects were given a number of written sentences and asked to read them aloud. Students' actual pronunciation was recoded in a quiet place utilizing an MP3 recording device (see appendix 1)

\subsection{Data Collection and Analysis}

The research subjects were asked to read aloud written sentences and this took approximately one minute. The collected data was replayed several times to analyzed manually to identify any differences between male and female students' pronunciation. The data was tabulated to represent frequency and percentages to show the accuracy and inaccuracy of students' pronunciation of sentences. Moreover, the total mean score of all correct and incorrect pronunciation of 12 items (regards intonation and stress) which performed by both female and male students was found out utilizing the following formula:

$$
\bar{X}=\frac{\sum_{i=1}^{n} X_{t}}{n}
$$

\subsection{Research Scope}

This research studied gender differences and concentrated on pronunciation. Moreover, it included students from the third and fourth year from the Department of English in the Faculty of Arts, located in Misurata. The data were collected using random sampling. Two pronunciation aspects were under exploration in the study, i.e. intonation and stress, to investigate the gender differences among the study participants.

\subsection{Ethical Consideration}

The research subjects had been told in advance that their utterances would be recorded for study purposes. Before the procedure of collecting data has begun, the participants were asked whether they would feel afraid by the fact of being recorded. When they knew that only the linguistic features would be analyzed, they felt more comfortable. Also, they were told 
that their participation would not influence on their study or grades, and have the right to withdraw from the study any time.

\section{Results and Discussion}

According to the collected data, the research results are presented and visualized on the following tables and figures.

Table 1: Intonation

\begin{tabular}{|c|c|c|c|c|c|}
\hline \multirow[t]{2}{*}{ Item } & & \multicolumn{2}{|c|}{ female } & \multicolumn{2}{|c|}{ male } \\
\hline & & Inaccurate & accurate & inaccurate & accurate \\
\hline \multirow[t]{2}{*}{1.} & frequency & 00 & 10 & 5 & 5 \\
\hline & percent & & $100 \%$ & $50 \%$ & $50 \%$ \\
\hline \multirow[t]{2}{*}{2.} & frequency & 1 & 9 & 5 & 5 \\
\hline & Percent & $10 \%$ & $90 \%$ & $50 \%$ & $50 \%$ \\
\hline \multirow[t]{2}{*}{3.} & frequency & 3 & 7 & 3 & 7 \\
\hline & Percent & $30 \%$ & $70 \%$ & $30 \%$ & $70 \%$ \\
\hline \multirow[t]{2}{*}{4.} & frequency & 2 & 8 & 6 & 4 \\
\hline & Percent & $20 \%$ & $80 \%$ & $60 \%$ & $40 \%$ \\
\hline \multirow[t]{2}{*}{5.} & frequency & 3 & 7 & 00 & 10 \\
\hline & Percent & $30 \%$ & $70 \%$ & & $100 \%$ \\
\hline \multirow[t]{2}{*}{6.} & frequency & 1 & 9 & 4 & 6 \\
\hline & Percent & $10 \%$ & $90 \%$ & $40 \%$ & $60 \%$ \\
\hline \multirow[t]{2}{*}{7.} & frequency & 3 & 7 & 7 & 3 \\
\hline & Percent & $30 \%$ & $70 \%$ & $70 \%$ & $30 \%$ \\
\hline \multirow[t]{2}{*}{8.} & frequency & 4 & 6 & 4 & 6 \\
\hline & Percent & $40 \%$ & $60 \%$ & $40 \%$ & $60 \%$ \\
\hline \multirow[t]{2}{*}{9.} & frequency & 2 & 8 & 7 & 3 \\
\hline & Percent & $20 \%$ & $80 \%$ & $70 \%$ & $30 \%$ \\
\hline \multirow[t]{2}{*}{10.} & frequency & 4 & 6 & 6 & 4 \\
\hline & Percent & $40 \%$ & $60 \%$ & $60 \%$ & $40 \%$ \\
\hline \multirow[t]{2}{*}{11.} & frequency & 2 & 8 & 3 & 7 \\
\hline & Percent & $20 \%$ & $80 \%$ & $30 \%$ & $70 \%$ \\
\hline \multirow[t]{2}{*}{12.} & frequency & 3 & 7 & 8 & 2 \\
\hline & Percent & $30 \%$ & $70 \%$ & $80 \%$ & $20 \%$ \\
\hline $\begin{array}{l}\text { total mean } \\
\text { score }\end{array}$ & & 0.23 & 0.76 & 0.48 & 0.51 \\
\hline
\end{tabular}

According to table 1, the major differences between female and male students' pronunciation are shown in sentences 1,9 , and 12. In item 1, all female students pronounced the statement with an accurate intonation pattern, on the contrary, only half of the male participants' actual pronunciation tended to be inaccurate. In item 9, only 2 of female students failed to pronounce the sentence correctly, while 3 of the males' pronunciation was correct. In item $12,70 \%$ of female students succeeded to pronounce the sentence correctly, while, $80 \%$ of male participants failed to pronounce intonation correctly. Generally, female students outperformed on male students in the pronunciation of sentences with accurate intonation patterns. However, in sentence 5, males' performance slightly exceeded the females'. 
Moreover, the total mean score of accurate pronunciation of the 12 items performed by female students was .76 and inaccurate pronunciation was .23. For male students' pronunciation, it was found out that there were no big differences between their accurate and inaccurate performances ( 0.51 and 0.48 respectively).

chart 1: intonation

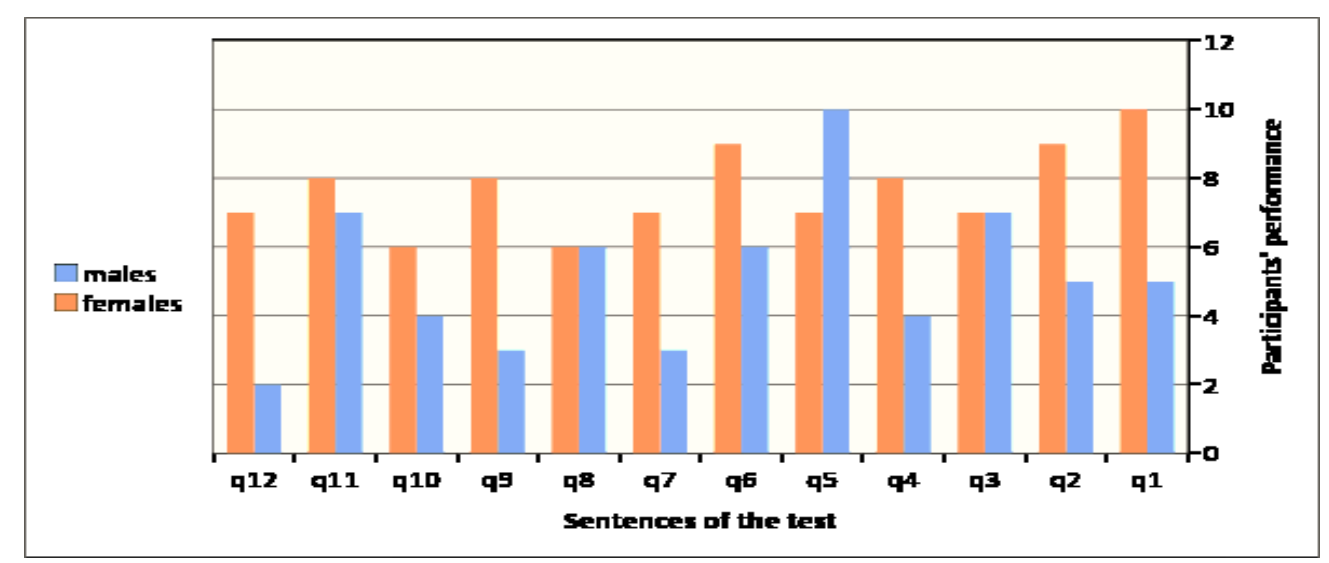

As seen in chart 1, which represents the same, yet in a more simple way, the research results, it was clear that item 12: (What's your sister's name?) was the most difficult to pronounce by male students. However, items 8 and 10 (That's wonderful! and Are you going to join us attending the party?) were the most ones female students failed to pronounce with correct intonation patterns.

Table 2: Stress item

male's pronunciation

\begin{tabular}{llllll} 
& & Accurate & $\begin{array}{l}\text { inaccurate } \\
\text { place }\end{array}$ & accurate & $\begin{array}{l}\text { inaccurate } \\
\text { place }\end{array}$ \\
\hline 1. & Frequency & 9 & 1 & 7 & 3 \\
& Percent & $90 \%$ & $10 \%$ & $70 \%$ & $30 \%$ \\
\hline 2. & Frequency & 5 & 5 & 4 & 6 \\
\hline \multirow{2}{*}{3.} & Percent & $50 \%$ & $50 \%$ & $40 \%$ & $60 \%$ \\
\hline 4. & Frequency & 6 & 4 & 4 & 6 \\
\cline { 2 - 6 } & Percent & $60 \%$ & $40 \%$ & $40 \%$ & $60 \%$ \\
\hline 5. & Frequency & 5 & 5 & 4 & 6 \\
\hline \multirow{2}{*}{6.} & Percent & $50 \%$ & $50 \%$ & $40 \%$ & $60 \%$ \\
\hline 7. & Frequency & 2 & 8 & 2 & 8 \\
\cline { 2 - 6 } & Percent & $20 \%$ & $80 \%$ & $20 \%$ & $80 \%$ \\
\hline 8. & Frequency & 8 & 2 & 5 & 5 \\
\cline { 2 - 6 } & Percent & $80 \%$ & $20 \%$ & $50 \%$ & $50 \%$ \\
\hline 9. & Frequency & 5 & 5 & 7 & 3 \\
\cline { 2 - 6 } & Percent & $50 \%$ & $50 \%$ & $70 \%$ & $30 \%$ \\
\hline 10. & Frequency & 6 & 4 & 5 & 5 \\
\cline { 2 - 6 } & Percent & $60 \%$ & $40 \%$ & $50 \%$ & $50 \%$ \\
\hline 11. & Frequency & 6 & 4 & 4 & 6 \\
\hline & Percent & $60 \%$ & $40 \%$ & $40 \%$ & $60 \%$ \\
\hline & Frequency & 4 & 6 & 1 & 9 \\
\cline { 2 - 6 } & Percent & $40 \%$ & $60 \%$ & $10 \%$ & $90 \%$ \\
\hline & Frequency & 4 & 6 & 5 & 5 \\
\hline
\end{tabular}




\begin{tabular}{llllll}
\hline & Percent & $40 \%$ & $60 \%$ & $50 \%$ & $50 \%$ \\
\hline \multirow{2}{*}{12.} & Frequency & 5 & 5 & 7 & 3 \\
\cline { 2 - 6 } & Percent & $50 \%$ & $50 \%$ & $70 \%$ & $30 \%$ \\
\hline \multirow{2}{*}{ total mean } & 0.52 & 0.33 & 0.45 & 0.45 & 0.54
\end{tabular}

score

Concerning research students' pronunciation of the given sentences with proper stressed words, table 2 reports that major differences focused on sentences 6 , and 10 where female students performance exceeded male students with a percent of 30 , still it was the largest difference can be identified between the two groups of research participants.

Moreover, in the first item, 9 out of 10 of female students pronounced the sentence with accurate stressed words, while only 7 of male students were able to identify the stressed words. According to accurate column in table 2, 60\% of female students were pronouncing sentence 3 with a proper stressed word, yet $40 \%$ of male students were accurate.

However, it is worth mentioning that in items 7, 11, and 12 male participants showed rather outperformance on female ones. In sentences 7 and 12 male performance exceeded female performance with a percent of 20. Furthermore, in item 11 male students pronounced the sentence with accuracy of $50 \%$ while female students' pronounced the sentence correctly with a percent of 40 .

As seen, the total mean score of accurate pronunciation of the 12 sentences said by female participants was 0.33 and inaccurate pronunciation was 0.45 . For male participants, it was found that their pronunciation with correct stress recorded 0.45 and for incorrect stress was 0.54 .

chart 2: stress

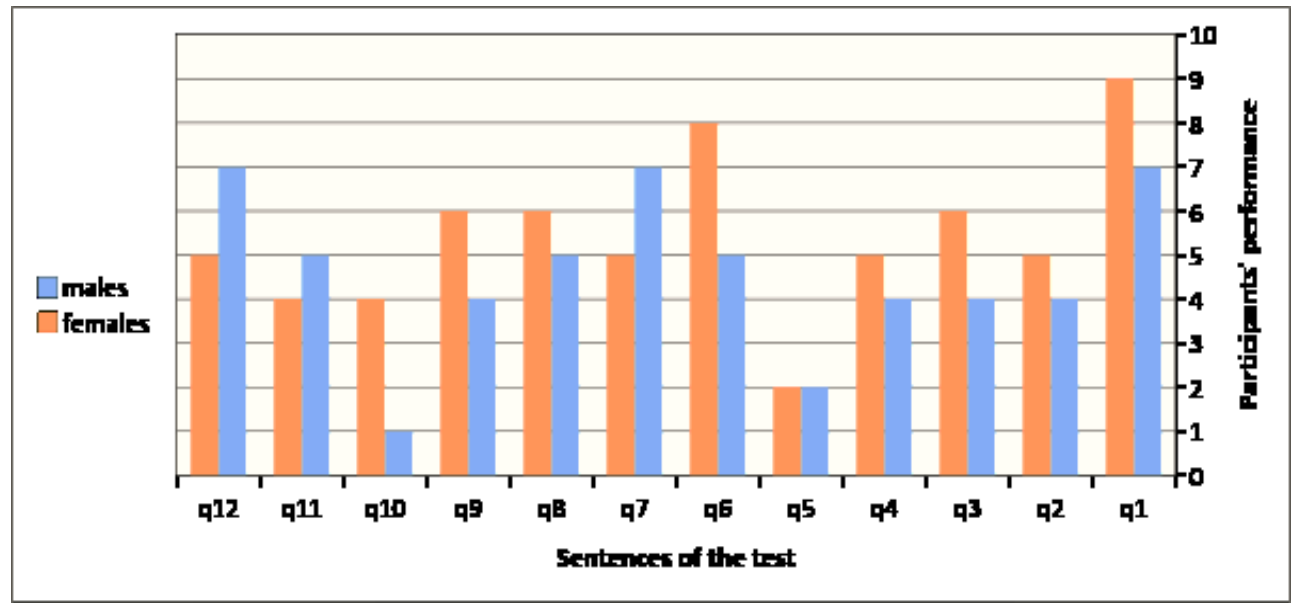

As shown in chart 2, it was clear that male students failed to identify the accurate stressed words in item 10 the most (Why did you do it?). However, items 5 (That's so nice of you) was the most problematic female students failed to pronounce with correct stressed words.

The results presented above lead to responding to the current research questions. As similar studies carried out on gender-related differences (Elwash and Hashem, 2015; Jinyu, 2014; Xiying, 2010), Libyan female and male students, as EFL learners, pronounced English differently and their use and recognition of accurate stress and intonation patterns varied. The 
two groups' performances were somehow different in intonation; there were only slight differences in identifying stressed words in the given sentences. In addition, male students tended to put stress on some right words, yet use improper intonation patterns. Female students' performances were not better than male ones in recognizing where the accurate stressed words, yet they were much better than male participants in identifying the proper intonation patterns of the given items. As Jinyu (2014), pointed out that many researchers and linguists have found out that "females have to pay attention to their methods and make sure they can make pure pronunciation while males relatively undisciplined and free pronunciation further reflect their prestige" (p. 94).

Therefore, the accuracy in sentence intonation was higher in female students' pronunciation than in male ones'. However, male students somehow outperformed female ones, in recognizing the right stressed words in several given items. However, in his review of literature on gender-based research of pronunciation accuracy, Hariri (2012) concluded that female outperformed male learners in producing accurate and clear sounds, but it is not significantly noticeable to result in complete dominance of female over male learners. Therefore, it can be concluded that there were gender-related differences in pronunciation between male and female participants in the current research, yet such differences were more prominent in one phonological aspect than the other one.

\section{Conclusion and Recommendations}

\subsection{Conclusion}

The relationship between gender and language has been studied; following different methodologies and various angles. Differences between males and females' language have been major focus of many sociolinguistics researchers. In the current research, two questions were addressed to find out any significant variations between Libyan learners of English as a foreign language:

1. Does gender influence learners' pronunciation significantly?

2. In what fields of pronunciation (intonation or stress) do male/female students perform better?

According to research findings reported above, it can be concluded that the total mean scores of accurate pronunciation, respecting intonation and stress of given items, performed by female and male participants were $0.76 ; 0.33$ and $0.51 ; 0.45$ respectively. Therefore, there were, yet not considerable, differences between female and male participants' pronunciation. Both groups have had some difficulties in recognition of the correct intonation pattern of given items and putting the stress on the right words. It is worth mentioning that female students generally outperformed male ones, though; male participants were slightly better than female ones in identifying the accurate stressed words.

\subsection{Limitations}

This research was carried out on a limited number of participants, yet more few participants could make the research more valuable. The researchers expected to include more participants, but shortage of time has concluded the research with twenty students only. 
Because the restrictive phonological aspects under investigation in the current research, it seems difficult to generalize the results to the whole Libyan speaker populations of English as a foreign language.

Besides, the research participants were given written sentences to read aloud, it is uncertain whether similar results would be obtained with spontaneous speech.

\subsection{Recommendations}

Language instructors need to be more attentive to their learners' individual differences, including gender-related ones. They can promote an inclusive classroom atmosphere, prepare stimulating activities, and interesting material to address both the female and male students' needs and differences. Such awareness is of an importance to invent thriving language learning environment and encourage students to overcome their weakness in language aspects.

Finally, it should be pointed out that the door is still open to take into account other possible factors and adopt comprehensive research methods to understand this phenomenon of language gender-related variations. Moreover, as many researchers have focused only on gender-related differences between women and men, but similarities have received no attention. As $\mathrm{Gu}$ (2013) proposed that "researchers should pay more attention to the similarities between the language of both genders" (p. 248)

\section{References}

Elwash, E. Hashem, E. (2015). Impact of gender and personality on second language speaking. (Unpublished bachelor's thesis). Faculty of Arts, Misurata University. Misurata.

Gu, L. (2013). Language and Gender: Differences and Similarities. International Conference on Advances in Social Science, Humanities, and Management. Retrieved from https://download.atlantis-press.com/article/10624.pdf

Hariri, M. (2012). A Review of Literature: A Gender-based Study of Pronunciation Accuracy. Research Journal of Applied Sciences, Engineering and Technology. 4 (22): Retrieved from http://maxwellsci.com/print/rjaset/v4-4861-4864.pdf

Holmes, J. (2013). An introduction to sociolinguistics. Harlow: Pearson.

Jinyu, D. (2014). Study on gender differences in language under the sociolinguistics. Canadian Social Science. 10(3), 92-96. doi: 10.3968/4602

Lakoff, R. (1975). Language and women's place. New York: Harper and Raw.

Longman dictionary of contemporary English. (2003). Harlow: Pearson.

Lyons, J. (1981). Language and linguistics, an introduction. Cambridge: Cambridge University Press.

Linde, H., Alex, R., Van Verde, F., Havenge, W., \& Visage, J.C. (2013). A theoretical and empirical analysis of gender differences in the African business 
environment.(Unpublished doctoral dissertation). North-West University, South Africa.

Meyerhoff, M. (2006). Introducing sociolinguistics. New York: Roultedge.

Nordquist, R. (2016). Sociolinguistics: Definition and examples. ThoughtCo. Retrieved from http://www.thoughtco.com/sociolinguistics-d-1692110.

Oxford Advanced learner's dictionary. (2006). Oxford: Oxford University Press.

Spolsky, B. (1998). Sociolinguistics. Oxford: Oxford University Press.

Trefry, R.G. (2017, November 20). What is Quantitative research? LIBRARY American Public University System. Retrieved from https://apus.libguides.com/research-methods guide/research-methods-quantitative

Wardhaugh, R. (2006). An introduction to sociolinguistics. United Kingdom: Blackwell Publishing.

Xia, X. (2013). Gender differences in using language. Theories and Practice in Language Studies. 3(8), 1485-1489. doi: 10.4304/tpls3.8.1485-1489

Xiying, F. (2010). A Study of Gender Differences in English Learning Strategies of Middle School Students. College of Foreign Language. Retrieved from http://file.scirp.org/pdf/18-1.1.1.pdf

\section{Appendices}

\section{Appendix A}

Written sentences given to the research participants:

1. Did you hear the sound?

2. How do you do?

3. Go over here.

4. Is it raining outside?

5. That's so nice of you.

6. I would like to buy a dress, shoes, and some accessories.

7. Have you seen my shoes?

8. That's wonderful!

9. Are you going to join us attending the party?

10. Why did you do it?

11. I will be back in a minute.

12. What's your sister's name? 